\title{
Correspondence
}

\section{World Psychiatric Association and the Royal College of Psychiatrists: regional reflections}

\section{Correspondence \\ is welcome on}

any of the articles

or issues raised

in International

Psychiatry. Letters

of no more than

500 words should

be sent to the

Editor, Hamid

Ghodse,

email hghodse@

sgul.ac.uk visit Sudan. by my former Keele colleague, Jed Boardman.
Sine I have just completed a journey 'up the - Nile'. This voyage began in Cairo, where I examined for the Arab Board, and ended at the source of the Nile in Uganda some days later. I was reminded of the life-giving energy of this great river and of the enriching vibrancy and humanity of its peoples, with their contrasting mental health services. Unfortunately, I could not on this occasion

The journey to Uganda was primarily a private visit to spend Christmas and New Year in a country I first lived in over 30 years ago. The timing of the visit was fortuitous, coinciding with the annual conference in Kampala of the Psychiatric Clinical Officers, and a visit

Both the World Psychiatric Association (WPA) and our College (one of its larger and most established member societies) are developing increasingly conspicuous and mutually enhancing regional policies. The fledgling College Africa Division could, together with the African Association of Psychiatrists and Allied Professions, provide a renewed focus for a realistic sense of 'African psychiatry'. The first African postgraduate textbook published for some decades, Essentials of Clinical Psychiatry for Sub-Saharan Africa (edited by Frank Njenga, Wilson Acuda, Vikram Patel and Mario Maj and published by the WPA), is a most valuable statement of new developments in postgraduate training and research.

The WPA, through its 18-strong Board of Elected Zonal Representatives, is also establishing a more tangible regional structure. The Asian Federation of Psychiatric Associations, for example, has been established, led by a distinguished Fellow of the College (Professor Parameshvara Deva), and the WPA President (Juan Enrique Mezzich) is committed to enhancing the contribution of member societies from low- and middle-income countries - and so am I. The energy and commitment of the psychiatrists in Uganda were self-evident, and the developments in mental health services now include a credible regional and district strategy.

It is now much to be hoped that the global energy witnessed at the World Congress in Cairo September 2005 will, like a Scottish salmon, move upstream, so that mental health services in the culturally rich but economically poor sub-Saharan Africa will be sustained. Here lies a challenge for our College and for the WPA.

Debates about a 'brain drain' are indeed important but we must listen carefully to those at the sharp end of personal decision-making and to colleagues living in countries where political instability is frequent. All strength to our College President, who has grasped this nettle and who articulated the issues succinctly at the WPA General Assembly. The increased institutional strength of the WPA and the evident will of the College to take seriously its international obligations are striking developments in our increasingly smaller world.

I plan to attend a regional meeting in Addis Ababa on 24-25 April 2006 and it is much to be hoped that the Board of International Affairs will also support the important WPA regional meeting planned for Nairobi in March 2007, to be hosted by the Kenyan Psychiatric Association with Frank Njenga and colleagues at the helm.

John Cox

Secretary General, World Psychiatric Association Past President, Royal College of Psychiatrists

\section{Psychiatry as a career: a trainee's perspective}

Cine thematic papers section discussing - recruitment into psychiatry in issue 10 of International Psychiatry (October 2005) provided thought-provoking reading. From its inception, psychiatry has struggled to convey its merits to medical graduates and consequently has suffered from low recruitment. I would like to report my experience of psychiatry as an undergraduate medical student in India and as a postgraduate trainee in the UK.

The first factor which influenced me as a graduate student was the stigma and prevalent negative attitude towards anything to do with mental illness. As pointed out by Bruce Tonge in that issue, one of the factors that deters graduates from making psychiatry a career choice is the fear of being held in low social regard by family and colleagues. The proportion of the health budget allocated to mental health was appallingly low in India, which hence affected the quality of care of patients, as well as undergraduate teaching. Access to journals was limited, and this prevented me from exploring the research base in psychiatry. However, when I undertook my clinical rotation in psychiatry I became deeply interested in the complex interactions of mental illness and the whole personality of the patient and the patient's surroundings. The interpersonal skills employed to communicate with patients were empathic and psychiatry seemed to have a more human touch than other specialties.

These experiences, though stimulating, were not strong enough for me immediately to embark on a career in psychiatry. After completion of my internship 